\title{
杉村楚人冠邸白馬城における庭の構成と維持管理の特徵
}

\section{A Study on the Character of Composition and Maintenance in Sojinkan Sugimura's Hakuba-jo Garden}

\author{
石川 有生* 荒井 歩** \\ Nao ISHIKAWA Ayumi ARAI
}

\begin{abstract}
Sojinkan SUGIMURA was a journalist of The Asahi Shimbun Company. He got a property which is located near the Teganuma Lake in Abiko, Chiba Pref. in 1912. After that, he named this property Hakuba - jo, had lived and ended his life until 1945. On this study, we narrowed the garden space of this property and aimed to clarify the feature as an old private garden by analyzing his essays, expense notes, old photographs and old survey maps. Especially, we examined next three aspects: 1) to clarify the location and surroundings as the place of residence, 2) to represent the spatial layout and to sort out garden elements which were made up through his country life, 3) to find his maintenance policy which was between natural growth and actual life. As a result, Hakuba - jo garden is characterized by the site specific feature and his sense of nature. On one hand, the property is spread from the hilltop to yatsu (small valley), a spring and a distant view of lake were taken in his life with the garden. On the other hand, the garden was covered with a mass of floral, colorful foliaged trees and wild grasses. The maintenance of these garden features were influenced by his 'rustic taste' which was confirmed as the natural style garden, the choice of plants, self - help maintenance, and the gardening lasted thirty years.
\end{abstract}

Keywords: Sojinkan Sugimura, Hakuba-jo, garden, Abiko, maintenance キーワード: 杉村楚人冠, 白馬城, 庭, 我孫子, 維持管理

\section{1. 研究背景と目的}

杉村楚人冠 (1872-1945, 以下, 楚人冠) は, 東京朝日新聞社の 記者を務めたジャーナリストである。本名は杉村広太郎であるが, 本研究では認知度の高い筆名の杉村楚人冠を用いる。楚人冠 は, 1912 (明治45)年に手賀沼のほとりにある現千葉県我孫子市緑 二丁目に土地を購入し，「白馬城」と名付けた別荘を造営した。そ の後楚人冠は, 関東大震災を機に一家でこの白馬城に転入し, 永眠 まで同地に居住した ${ }^{1)}$ 。

我孫子市は 2009 (平成 21) 年に白馬城の母屋や庭を含めた杉村 楚人冠邸の土地を取得した 2)。現在この土地は都市計画上「明田 緑地」という名称の緑地等である。2010(平成 22)年 1 月には杉 村楚人冠邸内の母屋，邸内最古の建造物で転居後は楚人冠の母の 住居となった澤の家（以後, 澤の家）, 茶室, 蔵の 4 棟が我孫子市 指定文化財に指定され, 2011 (平成 23) 年 11 月より「我孫子市杉 村楚人冠記念館」として一般公開された ${ }^{3)}$ 。庭部分も記念館に準 じて公開されている。公開に先立ち，上記建造物 4 棟は市の建造 物保存調査結果に基づき修復作業が行われた 4)。しかし庭部分は, ベンチや園路の新設等が市の都市公園整備事業として実施された。 この都市公園整備は，建造物修復の基準となった楚人冠存命期間 の庭を復原しているとはいいがたい。そこで, 楚人冠が存命中, 実 際に使用, 居住していた時代における白馬城の庭の構成や特徵を 整理し,今後の庭に関する整備方針を考察することは, 我孫子市の 文化財管理及び杉村楚人冠の人物研究において意義深いと考えた。 近代文化人邸宅の庭園の復原に関する既往研究としては, 古山 ら (2005)の正岡子規邸宅「子規庵」における庭の構成要素把握に 関する研究があげられる 5)。関連文学作品や古写真を資料として 庭の構成要素及び構成を把握し,それらの図上復原を図っている。 古山らの研究は文学作品等のテキストを活用した庭復原に関する 調査分析手法の提示でもあり，本研究はこの手法を援用した。一 方，正岡子規自身が直接関与したと想定される子規庵における庭 の維持管理の特徵には言及していない。
また楚人冠に関する既往研究には，小林康達の「『和歌山新報』 時代の杉村楚人冠」 ${ }^{6}$ (2002), 水野修身の「杉村楚人冠の雑誌『英 学』について」7)(2010)等がある。しかしそれらは楚人冠に関す るジャーナリズムや英学に関する研究が主であり, 白馬城の建造 物や庭等に関する研究はみられない。

そこで本研究では, まず楚人冠の人物像と白馬城の立地環境を 整理する。次に白馬城に関寸る楚人冠の随筆作品や支出帳, 古写真, 図面等を主な資料として,楚人冠が別荘を造営して永眠するまで の期間における白馬城の庭の空間構成と構成要素, 維持管理方法 の特徴を明らかにすることを目的とする。また，「我孫子市杉村楚 人冠記念館」における庭部分の整備方針について考察を行う。

\section{2. 研究方法}

(1) 楚人冠の人物像の整理

文献 1), 2), 8,9) と書簡・書類 ${ }^{10)}$ 等を用いて, 楚人冠の生誕力ら永眠 までの事項を把握し, その人物像を整理した。

\section{（2）白馬城の立地環境の把握}

白馬城が築かれていく様子が描かれている随筆集「白馬城」11) 及び, 1897 (明治 30) 年陸地測量部発行の $1 / 20,000$ の迅速測困 12 ) を用いながら白馬城の庭の立地環境を把握した。

\section{（3）庭の空間構成の把握}

本研究では, 庭の空間構成を把握するために随筆作品 (以後, 随 筆) 及び支出帳, 庭内を撮影した古写真, 白馬城見取圖, 現況平面図 を資料として用いた。随筆は, 白馬城での生活が描かれた短編作品 が収められた随筆集の中から庭の様子が描写された作品を「白馬 城」11)から 15 作品, 「湖畔吟」13)力ら 18 作品, 「続湖畔吟」14) 小 ら 29 作品，「続々湖畔吟」15)から 27 作品，「新選文」16)から 23 作品, 「とつおいり」17)から 7 作品, 計 119 作品を資料として抽出 した。支出帳は楚人冠が白馬城に関する支出を記帳した「白馬城 関係支出帳他」を用いた。これは現在杉村家で所蔵されている。 「白馬城関係支出帳他」で庭に関する支出として記帳された「木

*茅分崎市役所

**東京農業大学地域環境科学部造園科学科 
石類」（1912 年～1934 年),「木石二関スル雑費」（1912 年～1929 年)，「土工費」（1912 年～1928 年)，「建築及備品」（1912 年～ 1934 年)の部分を参照した。古写真は, 杉村家に所蔵されているも のの中で, 白馬城内において造営年である 1912(明治 45)年から 楚人冠の永眠年である 1945(昭和 20)年までの期間に撮影された 計 89 枚を資料として用いた。白馬城見取圖 18)には, 居住期の敷地 内における施設の配置と植栽の概要が示されている。現況平面図 19)は我孫子市で 2008(平成 20)年に作成したものを用いた。これ らの資料を基に, 庭内に存在した施設と植栽を把握した。また古写 真の撮影場所を明らかにし, 古写真に写された要素の位置を現況 平面図上に整理し,庭内の施設と植栽の位置を明らかにした。

\section{(4) 庭の構成要素の把握及び分析}

庭の構成要素を把握するため, 随筆から庭の構成要素(以下, 構 成要素) となる名詞を抽出し, それぞれ木本類, 草本類, 施設・工作 物類, その他のカテゴリーに分類した。次に, 全随筆中での構成要 素の出現回数をカウントし, 年代別で整理を行い, 構成要素の経年 的な増加, 減少と出現時期について分析した。これより 1 つの随 筆内で同一名詞が複数回出現する場合でも, 構成要素としては 1 作品中で 1 カウントとした。また, 随筆と支出帳を用いて構成要 素の入手方法, 入手時期, 数量についての整理を行った。

\section{（5）庭の維持管理方法の把握}

随筆中から庭の維持管理に関する文章を抽出し, 庭に対してど のような維持管理がなされていたのかを把握した。

\section{3. 研究結果}

\section{(1) 楚人冠の人物像}

楚人冠は 1872 (明治5)年 7 月 25 日に和歌山城下谷で生まれ, 15 歳で上京し, 英学, 仏教等の勉強を進めた。1903(明治 36)年 31 歳 の時, 東京朝日新聞社に入社し, 永眠するまでの 42 年間勤続した。 1907 (明治 40) 年と 1914 (大正 3) 年にロンドンに特派され, 海外 生活を経験する等国際派の記者であった。帰国後は, 海外で得た知 見を活かし, 日本初の新聞の縮刷版の刊行や記事審査部の創設等 を担当した。日本の新聞界の近代化を推し進めた一人である。

楚人冠は, 1912 (明治 45) 年に我孫子の土地を購入し, 別荘であ る白馬城を造営し, 1924(大正13) 年には関東大震災を機に一家で 転居した。そこで本研究では, 1912 (明治 45) 年から 1924(大正 13)年3月までを別荘期, 1924(大正13)年4月から 1945(昭和 20) 年 10 月 3 日までを居住期とした。

楚人冠は我孫子の白馬城における自らの生活を「湖畔吟」等の 随筆に描いた。また執筆活動以外にも我孫子の自然環境や景観に 関心を向け様々な活動を行った。まず 1913 (大正 2)年 11 月に手 賀沼開墾地整理基礎調査の結果が発表されると, 手賀沼の環境や 景観の尊さについての記事を同年 12 月の東京朝日新聞に 3 回に わたり連載した。また当時我孫子に別荘を所有していた嘉納治五 郎や村川堅固らと「手賀沼保勝会」を結成した。同会は手賀沼の 景観や自然環境を守るためには, 我孫子を観光地や郊外住宅とし て発展させることが望ましいとの考えを示し, 干拓反対運動を進 めた。1929(昭和 4) 年以降には, 我孫子ゴルフ俱楽部の建設提案, 俳句結社湖畔吟社の創立, 住民の風致活動への金銭的支援等を行 い, 我孫子での新たな文化と地域コミュニティの形成に貢献した。

\section{（2）白馬城の立地環境}

楚人冠は我孫子の散策時の印象を「帯のやうに流る〉手賀の湖, 對岸に糢糊たる松林や杉の森, 風にそよぐ岸の枯蒕, 琴の音に通ふ 松風の音, 何處を見ても全くよい。」20) とし, 我孫子の谷津地形の崖 線から眺められる手賀沼や葦原, 松林等の景観を描写している。楚 人冠が 1912 (明治 45$)$ 年に購入した白馬城の土地は,「お伊勢山と 歡音山との間の瘦せた麥畑」20) と「この地所にくツついた小さな 畠を二筆」21) であり, その後二反許りの「澤のやうに土地がおち

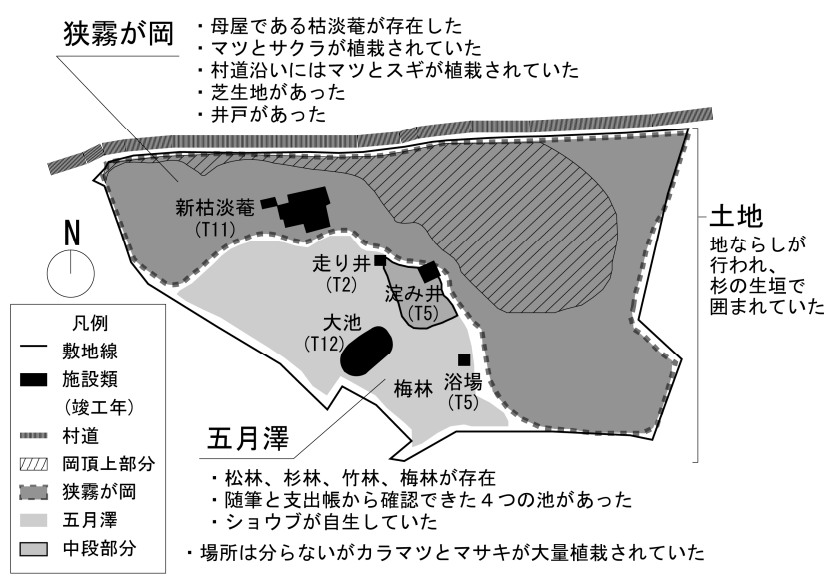

図 - 1 別荘期における庭の模式図

こんで,だらだらと緩勾配になつた畠」21)を手に入れ,この時点で 白馬城全体の総面積は約千坪余となった。1916(大正 5)年頃に楚 人冠が先二つの畑地を「狭霧が岡」21), 澤部分の畠を「五月澤」21) と名付けたことからも分かるように, 白馬城の土地は, 谷津の地形 ならではの高台, 斜面地, 低地を含んでいた。購入当初の白馬城の 土地は, 「町からは近いし, 沼も見はらせるが, 其の地所といふは凸 凹になつた砂地の畠で, 五十年位の松の樹が二本立つて, 肥料の利 かない瘦せた麥の芽がひよろひよろと生えて居るきり。」21) とある ような荒地に近い麦畑であったため, 楚人冠は「僕はいさ〉か悲歡 した」21) と土地への感想を述べている。しかし眺めの良さには満 足していたと考えられる 20)。実際に明治 20～30 年頃における白 馬城周辺は, 白馬城の南側の斜面地には松林が存在し, さらに斜面 地下の低地には帯状の水田, 蔁原, 湿地を隔てて手賀沼が広がって いた。これより, 手賀沼への眺望に優れた自然豊かで閑静な立地環 境だったと推測される。

\section{(3) 庭の空間構成}

\section{1）別荘期}

別荘期の庭は, 地ならしされた土地の周囲にスギの生垣が配さ れていた。狭霧が岡に枯淡菴と新枯淡菴が建てられ, マツ, スギ, サクラの植栽と芝生地が存在した。また五月澤には, 中段をつき崩 した場所に浴場が建設された。1912(明治 45)年から植樹が行わ れ, 松林, 杉林, 竹林, 梅林が存在した。また, 場所は不明だがカラマ ツとマサキが大量に植栽されていた。走り井と淀夕井と名付けら れた井戸と池が作られて以来, 五月澤には井戸と池が複数掘られ, 改修も頻繁に行われた。それらの配置と竣工年等を図 - 1 に模式 図としてまとめた。

2) 居住期

居住期の庭内に存在した施設類は, 母屋, 澤の家, 蔵, ガレージ, 鳩舎, メタンガス発生装置, 茶室, 浴場, 大池, 淀み井, 走り井, 観音 像, 門であり,これらの配置と竣工年を図 - 2 に整理した。この他 にも複数の池と井戸の存在が確認されたがその竣工年と配置は資 料からは分らなかった。

居住期を撮影した古写真の撮影場所を整理すると, 狭霧が岡部

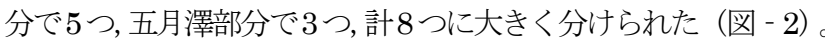
狭霧が岡部分の(1)門・ガレージ周辺は, 村道に沿って生垣が設けら れ, 横には芝生地が広がっていた。この芝生地では楚人冠がゴルフ の練習をしたり, 孫と遊ぶ様子が古写真から確認できた。さらに蔵 の周囲にはイチョウの大木, マツが植樹されていた。門を入るとす ぐにバラ棚があり, その周辺にはツバキの群植, 玄関の前にはサク ラが見られる等, 花木が多い場所であった。(2)母屋の濡れ縁前に は, 大木と鉢植え, 盆栽の存在が確認できた。南東方向には手賀沼 と対岸への眺望が, 東方向には林一の眺望が臨めた。随筆 22)には 


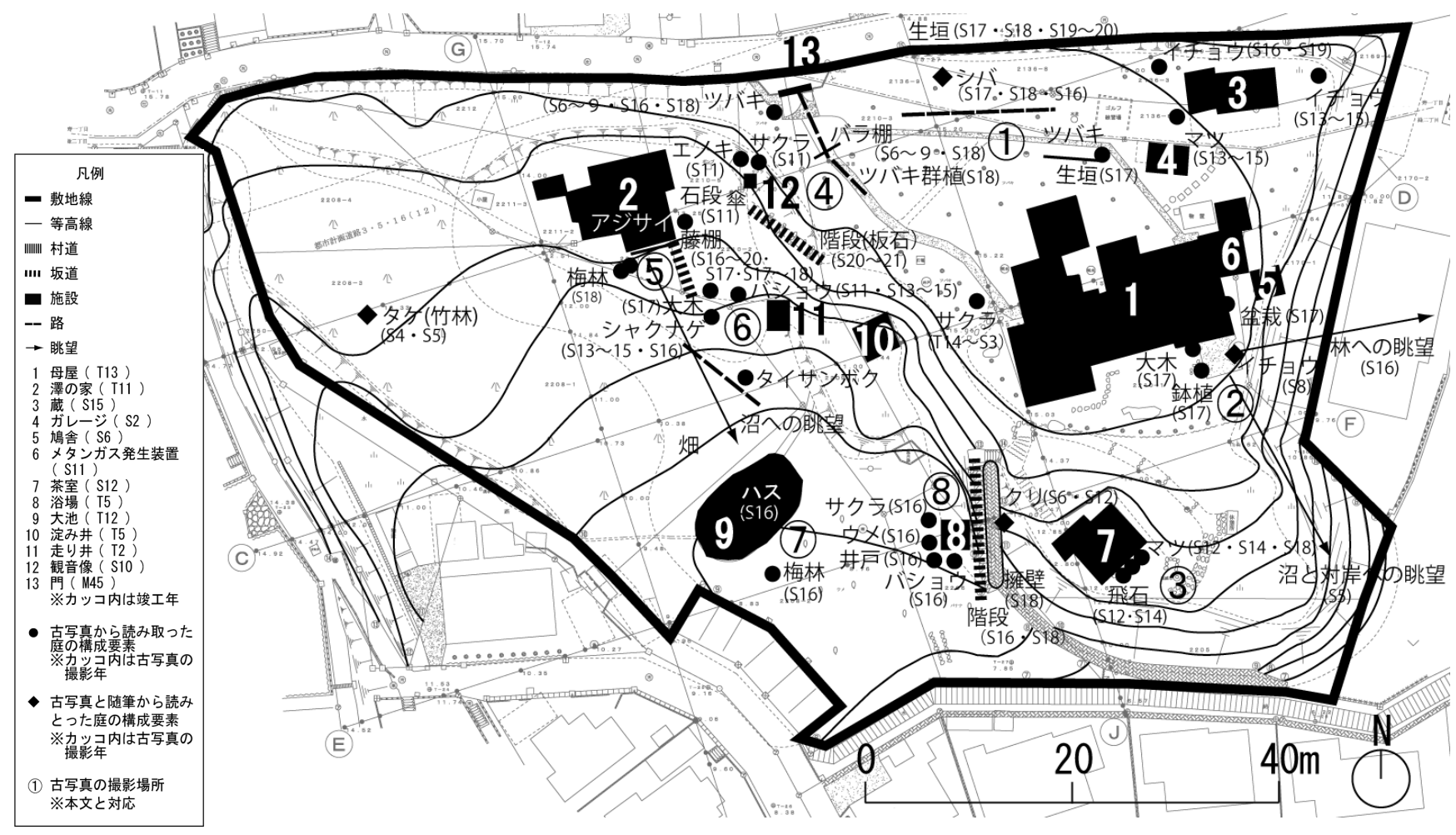

図 - 2 居住期における庭の空間構成 （現況平面図 ${ }^{19)}$ 上にプロット）

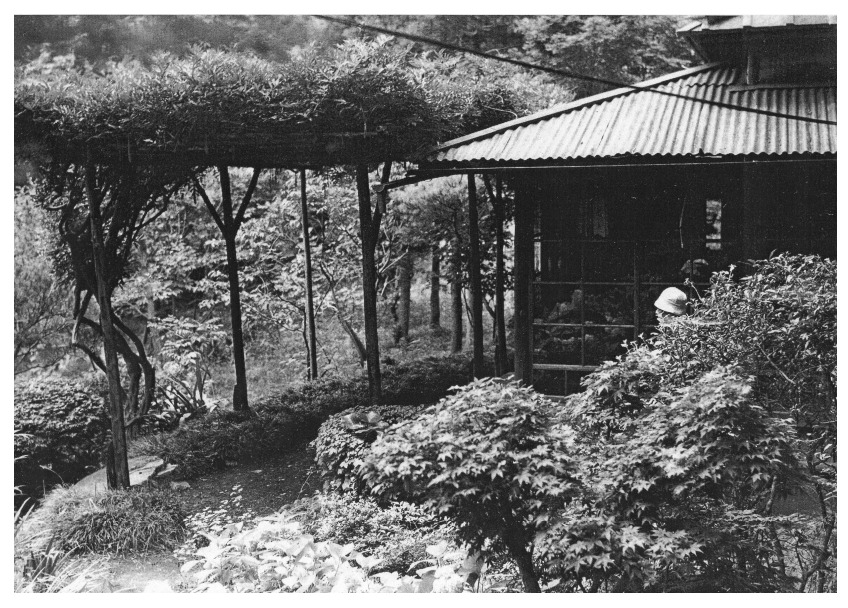

図 - 3 居住期（昭和）における澤の家付近

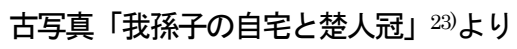

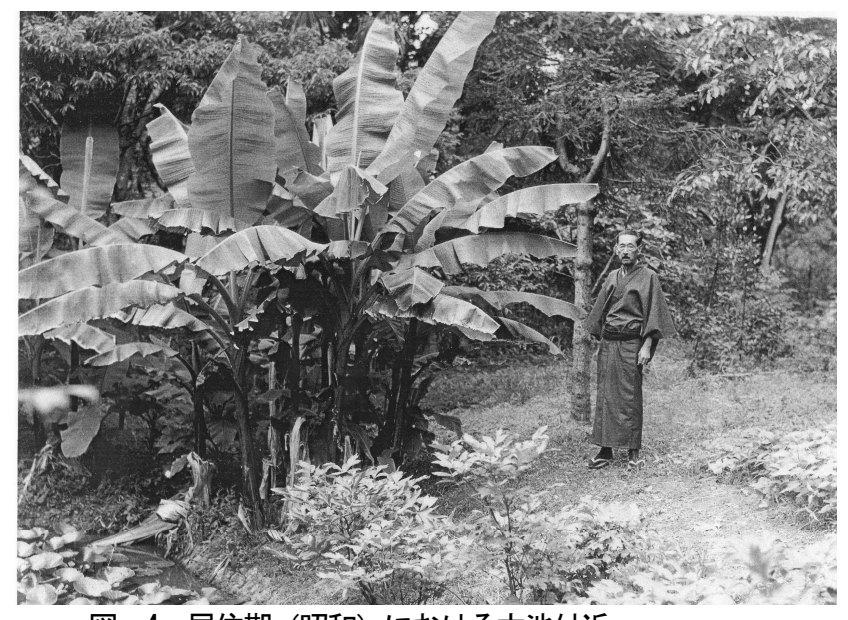

図 - 4 居住期（昭和）における大池付近 古写真「我孫子自宅周辺での楚人冠」23)より

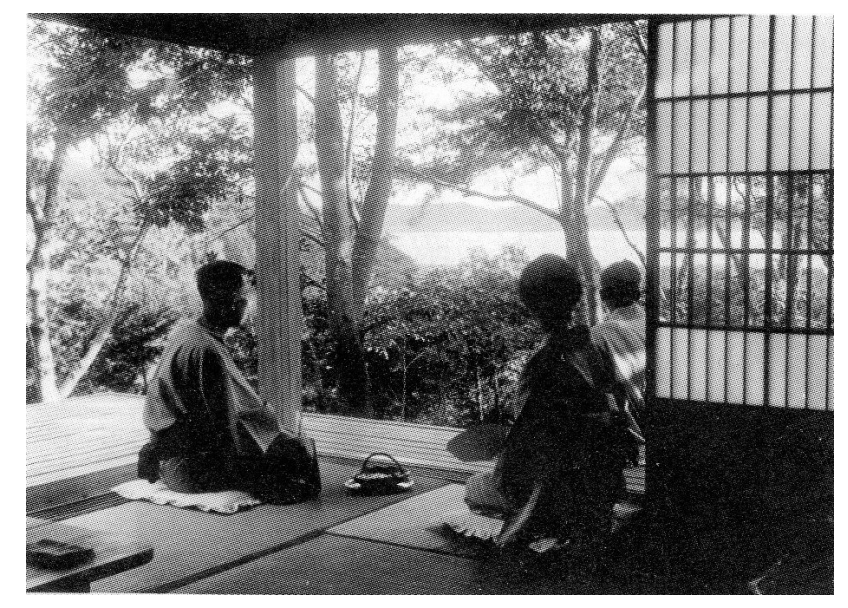

図 - 5 居住期における濡れ緣からの手賀沼への眺望 古写真「茶の間と濡れ縁」23)より

濡れ縁から手賀沼への眺めについて, 「遠くこの小松林を隔て〉隱 見する湖上に, いさ〉小船の二つ三つ往きかふのが, 如何にも眞夏 の曉らしい。」22) と描写されており, 母屋の濡れ縁からは, 庭内の小 松原や草花, 庭樹を隔て, さらに松山や水田を超えて手賀沼が広が る景観が眺められ, 時に水面には舟の姿も見られたことがわかっ た。(3)茶室前ではマツ, 飛石, 灌木類が存在した。五月澤部分の(4) 観音像安置場所周辺は, 観音像が狭霧が岡から澤の家に下る階段 の中腹に安置された。観音像付近には玉石の石段や木材で作られ た観音像用の傘があり, 野趣あふれる様子が伺えた。また, 観音像 の横にはサクラとエノキの大杖あった。(5)澤の家前では, 母のた めに設えられた藤棚があり, さらに藤棚の南側に梅林が広がって いることが確認された。また澤の家の西側にはアジサイを含む灌 木類が存在した。また, 澤の家からも手賀沼が眺められた。(6)大池 と澤の家の間には, 澤の家から下る階段を下りた場所にバショウ やシャクナゲ, タイサンボクの植栽が見られ, 位置は特定できなか ったがカエデ等の大木が複数存在していた。さらにそれらの南側 
は一部畑として利用されていた。(7)大池周辺では, 大池の水面に八 スが見られ, さらに池の南東側には梅林が広がり, 池の汀にバショ ウの群生が存在した。8浴場周辺では, 浴場の東側に浴場へと下り

\section{表 - 1 別荘期と居住期における随筆から抽出した構成要素}

\begin{tabular}{|c|c|c|}
\hline & & 庭の構成要素（ カッコ内は出現回数、1回の場合は省略） \\
\hline \multirow{4}{*}{ 兵 } & $\begin{array}{l}\text { 木本類 } \\
\text { ( } 7 \text { 要素) }\end{array}$ & $\begin{array}{l}\text { マッ・ヒメコマッ(3) / ウメ (3)* / キリ (2) / マダケ・タケ (2)*/ } \\
\text { スギ/ヒノキ/サクラ }\end{array}$ \\
\hline & $\begin{array}{l}\text { 草本類 } \\
\text { (4要素) }\end{array}$ & ショウブ(2) / コウライシバ / ックシ / セリ \\
\hline & $\begin{array}{l}\text { 施設 · } \\
\text { 工作物類 } \\
\text { (10要素) }\end{array}$ & $\begin{array}{l}\text { 小坂・坂・坂道 (3)/杉の生垣/井戸/走り井/小池（しじみの池）/ } \\
\text { 瀧・瀧壹/淀み井/湯殿/長州風呂・長州風呂の底板 (2)/小さな池 }\end{array}$ \\
\hline & $\begin{array}{l}\text { その他 } \\
\text { (6要素) }\end{array}$ & 不斷の泉・清水 (3) / 松露 / 初茸 / たらひ / 茸（汗茸）／細流 \\
\hline \multirow{4}{*}{$\begin{array}{c}\text { 庭 } \\
\text { の } \\
\text { 構 } \\
\text { 成 } \\
\text { 要 } \\
\text { 素 } \\
\text { に } \\
\text { お } \\
\text { け } \\
\text { る } \\
\text { カ } \\
\text { テ } \\
\text { ゴ } \\
\text { リ }\end{array}$} & $\begin{array}{l}\text { 木本類 } \\
(60 \text { 要素 })\end{array}$ & 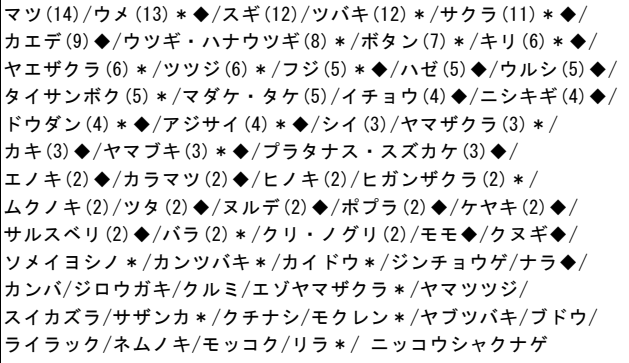 \\
\hline & $\begin{array}{l}\text { 草本類 } \\
\text { (31要素) }\end{array}$ & 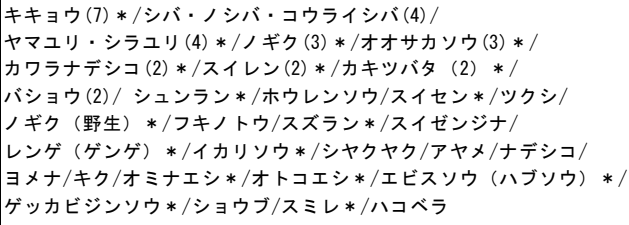 \\
\hline & $\begin{array}{l}\text { 施設 } \\
\text { 工作物類 } \\
\text { (24要素) }\end{array}$ & 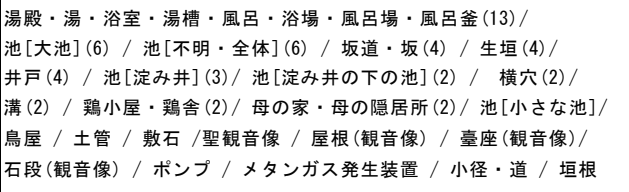 \\
\hline & $\begin{array}{l}\text { その他 } \\
\text { (10要素) }\end{array}$ & 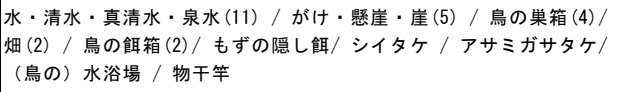 \\
\hline
\end{tabular}

※けは紅葉についての記述，はは花についての記述があった構成要素を示す。 構成要素にに母屋は含めておらず, 要素の名称は文中の表記をそのまま用いた。 ただし動植物は分りやすさを考慮し,カナカナに変換した。

\section{表 - 2 構成要素における年代ごとの出現回数と初回出現要素数}

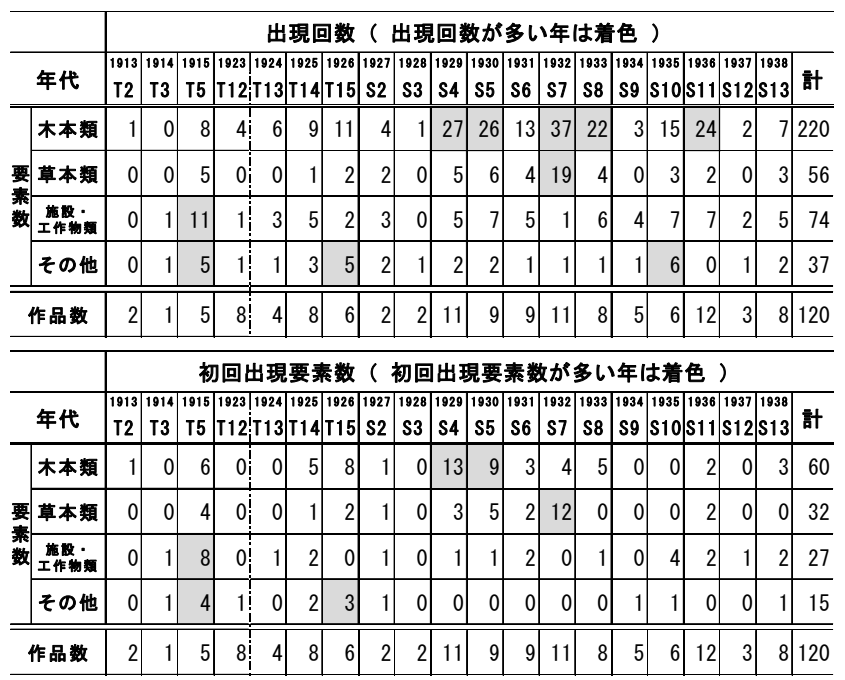

る丸太の階段と擁壁が存在した。浴場の周辺にはサクラ, ウメ,バ ショウが植栽され, 浴場の南西にあたる位置に井戸が確認された。

\section{(4) 庭の構成要素}

1) 構成要素

i ) 構成要素数

随筆からは別荘期と居住期を通して木本類 60 要素, 草本類 32 要素, 施設・工作物類 27 要素, その他 15 要素を抽出した (表 - 1)。

ii ）構成要素の出現回数

随筆中での構成要素の出現回数は, 木本類が 220 回と, 各カテゴ リー中で最も多かった(表 -2 )。草本類の出現回数は56回であり, 木本類には及ばないものの, 構成要素数は 32 要素と多様であった。

さらに, その年に随筆中で初めて出現した要素が何種あったか (以下, 初回出現要素数) を整理した結果, 木本類, 草本類の出現回 数, 初回出現要素数は 1929 年から 1933 年頃に増加する傾向が見 られ, 庭では居住期にあたる 1929(昭和 4) 年から 1933(昭和 8) 年 頃までに植物の種類が増加していたことが推測された(表 - 2)。 施設・工作物類は, 別荘期にあたる 1915 (大正 5) 年頃にその多く が設えられたと考えられ, それ以降は 1928(昭和 3) 年等以外は継 続的に作品中に書かれていた。

2) 木本類, 草本類における構成要素の特徴

i ) 構成要素の種類

木本類で出現回数が多い構成要素は, マツ, ウメ, スギ, ツバキ, サクラ, カエデ等であった(表 - 1)。また木本類の中では, カエデ, 八ゼ等紅葉の描写を伴う要素が 24 要素と多く抽出された(表 - 1)。 主に「宅の楓といふ楓は, 一二本を除いてあとは, 眞赤に紅葉しな いで,ことごとく黄色く染つた。それが又とても美しい。」24)とい ったように, 紅葉の色等が描写され, 「美しい」,「よい」等紅葉に 対して好意的な感想が多く見られた。中でも楚人冠は葉が黄色に 染まる様子を好んでいた。また, カキ等の結実する樹木も複数見ら れた。次に草本類では, キキョウ, シバ・ノシバ・コウライシバ等 が出現回数が多かった(表 - 1)。これらは, 1929 (昭和 4) 年以降の 出現回数が目立った。さらに草本類では, シュンランやオミナエ シ等山道沿いに咲き, 草丈が膝丈以上になる草が多かった。また,

「下らぬ西洋草花のどくどくしいのが, 無上に幅を利かせてるる 今の世」25) と述べていることから, 楚人冠は園芸種や西洋種は好ん でいないかったことが伺え, 構成要素中でも少なかった。木本類と 草本類では, 共通して花の描写を伴う要素が多かった。木本類では ツバキ, サクラ等の 23 要素, 草本類ではスズラン,イカリソウ等の 18 要素であった(表 - 1)。「大輪の椿が枝もたわ〉に咲いてみる。晚 ざきの八重櫻が, か壮色の葉の間に薄桃色に入り亂れてるる。冬の間 はこ〉にこんな木があつたとも覺えぬ庭のところどころに, 赤白のつ つじが一面に花をつけてみる。櫻の大机からみつくに任せた白藤が, はるかの枝から垂れ下つてくる。」26)や，「庭に下り立つと, 得ならぬ 沈丁花の香が春の來たのを知らせる」27)といったように花色や香りの 描写が多かった。またツバキやサクラでは,「中にもツバキは秋咲 のワビスケを始とし, ヨトメやシラタマやダイカグラが, 我おくれ じと, 花やかな花をつけた。」28)や,「普賢象, 日暮, 深山の匂と知れ た。 29) といったようにその品種についての記述もあった。また, 木本類ではウメやサクラ等冬から春頃に咲くものが多く, 草本類 ではスイレンやオオサカソウ等初夏から秋にかけて咲くものが多 かった。これより白馬城では 1 年に渡って花を楽しめたことが推 測された。さらに，「朝早く起きて,かういふ花の中を歩くのが前 の夜から待たれて, 春眠正に曉を覺える。かうしてこの花の間をぶ らぶらするだけでも, この世に生き甲斐のある心地がする」26) とい う記述からも, 花を愛する楚人冠は, 庭に花木を積極的に植樹して いたことが考えられる。

ii）構成要素の入手方法

入手方法は, 買い取る・購入する, 取り寄せる, 移植する, 交換す 
表 - 3 木本·草本類における構成要素の入手方法, 入手時期, 数量

\begin{tabular}{|c|c|c|c|c|c|}
\hline & 木本類 & 草本類 & & 木本類 & 草本類 \\
\hline $\begin{array}{l}\text { 入 } \\
\text { 手 } \\
\text { 方 } \\
\text { 法 } \\
\text { 入 } \\
\text { 手 } \\
\text { 時 } \\
\text { 期 }\end{array}$ & 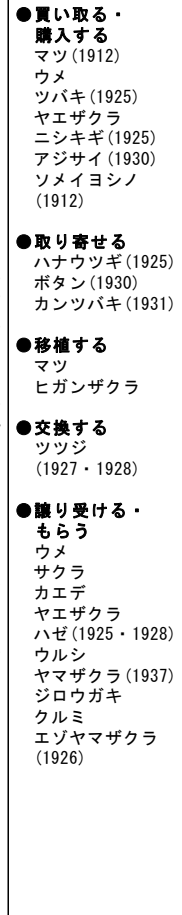 & 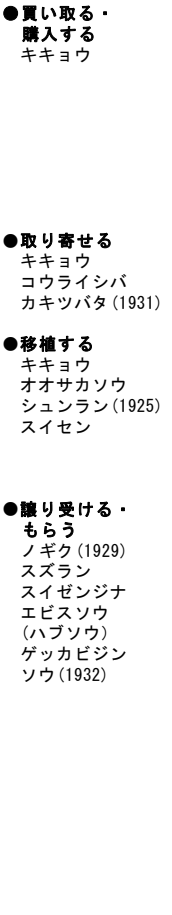 & $\begin{array}{l}\text { 表 } \\
\text { 記 } \\
\text { は } \\
\text { 文 } \\
\text { 中 } \\
\text { の } \\
\text { ま } \\
\text { ま }\end{array}$ & 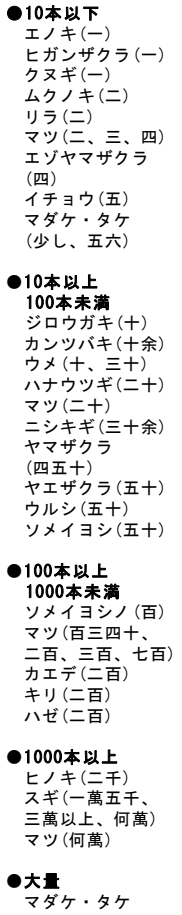 & 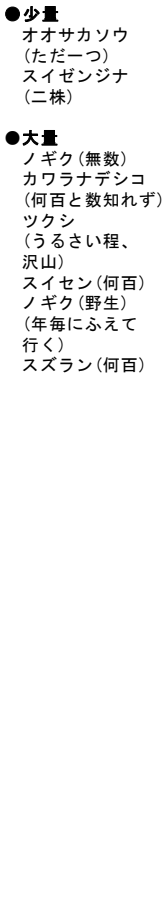 \\
\hline
\end{tabular}

表 - 4 支出帳「木石類」における年代ごとの支出合計金額と記帳 のあつた構成要素名

\begin{tabular}{|c|c|c|}
\hline 年代 & 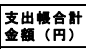 & 支出帳に記帳された構成要素 ※( ) 内は数量 \\
\hline $\begin{array}{l}1912 \\
M 45\end{array}$ & 144.650 & 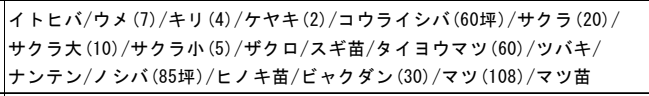 \\
\hline $\begin{array}{c}1913 \\
\mathrm{~T} 2\end{array}$ & 60.750 & アンズ/キャラ/サクラ(2)/サザンカ/シイ/スギ/ツバキ/フジ/ミカン(6) \\
\hline $\begin{array}{c}1914 \\
\mathrm{~T} 3\end{array}$ & 9.750 & ケヤキ(10) / モッコク \\
\hline $\begin{array}{c}1915 \\
\mathrm{~T} 4 \\
\end{array}$ & 17. 200 & ウメ (2)/サクラ/マツ小 (300)/マツ大 (400)/モクレン※「木蓮花」との記帳 \\
\hline $\begin{array}{c}1916 \\
\mathrm{~T} 5\end{array}$ & 39.530 & $\begin{array}{l}\text { ウメ(18)/カエデ/コウメ/ザクロ/ツゲ/ヒイラギ/フジ(1)/ヤエザクラ/ } \\
\text { ヤマブキ }\end{array}$ \\
\hline $\begin{array}{c}1917 \\
\mathrm{~T} 6 \\
\end{array}$ & & 記帳なし \\
\hline $\begin{array}{c}1918 \\
\mathrm{~T} 7 \\
\end{array}$ & 11. 140 & ウメ(3) / タイサンボク \\
\hline $\begin{array}{c}1919 \\
\mathrm{~T} 8\end{array}$ & & 記帳なし \\
\hline $\begin{array}{c}1920 \\
\mathrm{~T} 9\end{array}$ & 3. 200 & マツ苗(支出帳「木石二関スル雑費」より) \\
\hline $\begin{array}{c}1921 \\
\mathrm{~T} 10 \\
\end{array}$ & 2. 000 & マッ(支出帳「木石二関スル雑費」より) \\
\hline $\begin{array}{c}1922 \\
\mathrm{~T} 11 \\
\end{array}$ & 5. 400 & ゲッケイジュ(3) / ヒマラヤスギ(3)／マツ苗 \\
\hline $\begin{array}{c}1923 \\
\mathrm{~T} 12 \\
\end{array}$ & 43. 000 & カラマッ(1000) / スギ苗 / マサキ(400) / マツ苗 \\
\hline $\begin{array}{c}1924 \\
\mathrm{~T} 13 \\
\end{array}$ & 11.650 & キリ苗(5) / サクラ苗 (25) / ハジ苗 / バラ苗(10) \\
\hline $\begin{array}{c}1925 \\
\mathrm{~T} 14 \\
\end{array}$ & 61.260 & 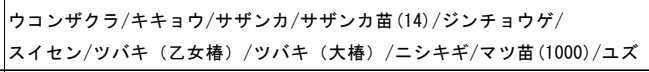 \\
\hline $\begin{array}{c}1926 \\
\mathrm{~T} 15 \\
\end{array}$ & 75. 500 & カイドウ / カエデ(64) / ハナショウブ(10株) / ヒノキ苗(230) / ユズ(3) \\
\hline $\begin{array}{c}1927 \\
\text { S2 }\end{array}$ & 37. 000 & シイ苗(50)／スズカケ／ヒノキ苗／ヒバ(40)／ボタン \\
\hline $\begin{array}{c}1928 \\
\text { S3 }\end{array}$ & 26. 000 & クルメッッジ(20) / ッバキ苗 \\
\hline $\begin{array}{c}1929 \\
\text { S4 }\end{array}$ & 12. 800 & ショウブ／ヒノキ苗／マッ苗 \\
\hline $\begin{array}{c}1930 \\
\text { S5 }\end{array}$ & 31.000 & サザンカ (10)/ツバキ (大椿・3)/ツバキ (寒椿) /ツバキ(18)/ボタン (5) \\
\hline $\begin{array}{c}1931 \\
\text { S6 }\end{array}$ & 34. 190 & アジサイ / ツバキ(18) / ッバキ(枝無椿) / ハイビスカス \\
\hline $\begin{array}{c}1932 \\
\text { S7 }\end{array}$ & 70.890 & 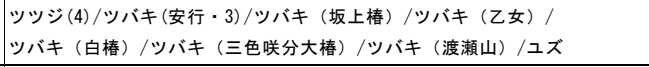 \\
\hline $\begin{array}{c}1933 \\
\$ 8\end{array}$ & 29. 780 & ツバキ(安行・6) / ツバキ（渡瀬山）／サザンカ \\
\hline $\begin{array}{c}1934 \\
\text { S9 }\end{array}$ & 53. 430 & ツバキ (安行・6) / ツバキ(安行・追加）／サザンカ（100) \\
\hline
\end{tabular}

る, 譲り受ける・もらうの 5 項目に分類できた(表 - 3)。楚人冠は 購入するだけでなく様々な方法で植物を入手していた。

iii）構成要素の入手時期

楚人冠は居住期(1924 - 45) において, 1920年代には 1930 年代 に比べて, より多様な入手方法で多種の植物を入手していた(表 3)。一方, 支出帳上では 1930 (昭和 5) 年から 1934(昭和 9) 年にか けて乙女や白椿等様々な品種のツバキを合計 47 本, 総額 185.03 円購入していた(表 - 4)。随筆中に「つばきは他國に見られぬ日 本の名花である。」30),「あの厚ぼッたい黑すんだ葉の間に, あの花 やかな大きな花がさき亂れるといふところに, 一種神祕的な趣が ある。」31) と述べられているように楚人冠は庭樹の中でもツバキを 特に愛した。

iv) 構成要素の数量

庭に 100 本以上植栽された植物は, 出現回数が多い要素であっ た。また, 1000 本以上植栽されたマツ, スギ, ヒノキは全て別荘期 に植栽された要素であり,これらは支出帳でも確認できた(表 4)。また草本類は,群植される傾向にあった(表 - 3)。

\section{（5）庭の維持管理の特徵}

別荘期から居住期まで一貫して見受けられた維持管理の特徵と して，「植木屋から庭樹にふさはしい松を取り寄せたのでは, 金ば かりか〉つて, 僕の手におへめ」32) とあるように, 楚人冠は金をか けずに庭の維持管理を行うべきと考えていた。しかし, 支出帳「木 石類」の記帳がなされた期間内では, 楚人冠はほほ継続的に新たな 植物を購入し続けており, 庭に対して全く金をかけないという訳 ではなかった(表－4）。次に「樹を植总て見たり拢いて見たり，池 を掘つて見たり埋めて見たり,氣のかはる毎に色々とかへて見て 過去五年の間に, 隨分永い樂を與へられた」33)等より, 楚人冠は自 ら維持管理を行うことを楽しんだ。

そして別荘期から居住期で変化した特徵としては, 別荘期は庭 のスギに対して，「根乎として森のやうになつてみる。これがす い〉と延びて行くのを見てみると，もう金づくで得難い愉快を感 じる」32）と述べ,積極的に植樹し，かつ樹木の生長を好意的に捉え ている。しかし 1929(昭和 4) 年には，「十七八年前にこ〉へ植总 つけたさまぐの樹が, すく〉と丈が延び, ぬう〉と八方に枝をひろ げ, 道をふさぎ, 空を蔽うて, 見るからに爵陶しくなつて來た」34) と,䭳蒼とした庭樹の状態を嫌い,「年々隨分思ひ切つて伐り倒す」 34) とあるように, 自ら植栽した樹木の伐採を始めるようになった。 また植木屋に手入をさせてこなかったことについて「初めて㼑然 としてその非を悟つた」34)とあり, 庭樹の管理の重要性を認識しは じめていた。

また, 居住期にあたる造営 20 年程を過ぎた 1932 (昭和 7) 年から 1935(昭和 10) 年の間の記述からは，「花はなべて道行く人にも喜 ばれるやうに植总てある。」26)とのように, 自分だけでなく村人か らも喜ばれる庭づくりを目指していたことが伺えた。さらに 1932 (昭和 7) 年頃からは, 「花壇を作って, そこへ草花を植总るや うなことは, どうにも自分の好みにあはない」35)，「宅の庭には一 本も作つた花はない。生えるがま〉に所かまはず生えさせて, そこ らで勝手に花の開くに任せてある。」35)，「いくらうづ高くなつて も, 宅では落ち散るに任せて, 決して掃かせない。掃けば綺麗には ならうが, それは醜女のけはひしたるに似て, 私はそのわざとらし さを厭ふ。自然のま〉にすておく方が趣を見せる。」36)等, 花壇の 設置や落葉を掃き清めたような, 作り込んだ庭を野暮に感じるよ うになった。落葉が一面を埋めつくす景色を「そこへ木鼠なんぞ がかさこそと出て來さうな氣はひがして, 如何にも人の世を離れ た野趣が見える」37) と捉え, 野趣あふれる自然風な庭を好む傾向が 強まっていった。 


\section{4. 考察}

白馬城の庭における特徴を以下 3 点に分けて考察した。

\section{（1）立地・敷地面の特徵}

高台である狭霧が岡には母屋や澤の家等の居住施設, 低地であ る五月澤には池や風呂等が設置されていることから, 我孫子の谷 津といら地形的特徵を活かし，眺めや湧水を考慮した庭であった。 また資料から空間構成が明らかとなった白馬城の庭の主となる部 分は, 現在の杉村楚人冠記念館の敷地内に位置していた。

\section{（2）植栽の特徵}

白馬城の庭は楚人冠の意思に伴って維持管理が行われ, 荒地の 状態から緑豊かな空間へと変化していった。多数の植物が五月澤 と狭霧が岡に偏ることなく植栽されていた。また別荘期には $1 つ$ の樹種を大量植栽する傾向がみられたが, 居住期に入ると多様な 木本類, 草本類を植栽する傾向へと変化していった。楚人冠が特に 好んだツバキを中心とする花木や，紅葉が愛でられる樹木が意図 的かつ豊富に植栽されていた。また野草類が群植され，自然風の 野趣あふれる作庭が行われていた。これらの整理により楚人冠が 啫好した植物が明らかとなった。

\section{(3) 維持管理の特徵}

楚人冠は, 様式美の観賞を目的と寸る庭を目指したのではなく, 庭の維持管理を定期的に庭師に頼むこともしていなかった。楚人 冠は, 自らが庭の維持管理を行うこと自体を楽しんでおり,植樹や 剪定等は，歳月を費やしながら様々な試行錯誤を重ねていたこと が明らかとなった。

また楚人冠が好んだ庭の維持管理方針は,整形的でなく自然的 な庭を目指寸というものであり，その方針は, 随筆の文中でも多 用される「野趣」という言葉に代表される。

白馬城の庭は，谷津という地形的特徵を十分に活かした空間構 成であり,植栽や維持管理に楚人冠の趣味, 啫好を多大に反映しな がらつくりあげられたという特徴を持つことが明らかとなった。 また, 別荘期よりも居住期の庭の方が, これらの特徵が強く出てい た庭であったと推察できる。我孫子市杉村楚人冠記念館」におい ては, 庭部分が楚人冠の人物像を伝える史料の一つとして継承さ れるためにも, 上記の特徵を踏まえた庭の整備が必要である。さら に，「自然のま〉にすておく方が趣を見せる」36)等の文中の言葉に 代表される野趣性といった楚人冠の啫好を庭部分の維持管理方法 にいかに反映させるかの検討が重要であると考える。また，今回 明確にならなかった構成要素や空間構成の変化時期を明らかにす ることが今後の課題である。

謝辞

本研究を行うにあたり,楚人冠の生涯や人物像についてご教授 頂きました杉村楚人冠研究会の皆様, 多方面でご助言を頂き, 資料 提供, 調査にご協力を賜りました我孫子市教育委員会生涯学習部 文化・スポーツ課ならびに我孫子市杉村楚人冠記念館の皆様には, 厚く御礼を申し上げます。

\section{補注及び引用文献}

1) 我孫子市教育委員会 (2010)：第 4 回杉村楚人冠展 楚人冠と 景観保護活動

2）辻史郎（2010）: 杉村楚人冠〜我孫子と手賀沼を愛した文人 : 我孫子市教育委員会

3) 我孫子市教育委員会: 平成 23 年度第 1 回我孫子市文化財審 議会会議録 : 我孫子市ホームページ

〈http://www. city. abiko. chiba. jp/index. cfm/21, 63703, c, html/63703/20121012 - 150210. pdf> 2012.12.9 参照

4) 我孫子市教育委員会: 平成 22 年度第 1 回我孫子市文化財審
議会会議録：我孫子市ホームページ

〈http://www. city. abiko. chiba. jp/index. cfm/21, 63703, c , html/63703/20121012 - 143724. pdf > 2012.12.9 参照

5）古山道太・服部勉・進士五十八 (2005) : 正岡子規の庭園観・ 植物観と子規庵庭園 $(1894$ 1902) の図上復原: ランドスケー プ研究 68(5), $377-380$

6) 小林康達(2002-04) :『和歌山新報』時代の杉村楚人冠 : メ ディア史研究(12), $73-94$

7) 水野修身 (2010) : 杉村楚人冠の雑誌『英学』について : 英学 史研究 (43), 44 - 46

8）小林康達(2005)：七花八裂 - 明治の青年 杉村広太郎伝 - : 現代書館

9) 美土路昌一(1963) : 杉村楚人冠 : 三代言論人集第八巻 : 時事 通信社

10）杉村家蔵 我孫子市教育委員会提供, 書簡 22 点, 書類 4 点

11）杉村楚人冠(1937) : 白馬城 : 楚人冠全集第 1 巻 : 日本評論 社, 1 - 68

12）陸地測量部(1887 - 1897) : 2 万分の 1 迅速測図 : 我孫子宿取 手駅龍箇崎村

13）杉村廣太郎 (1928)：湖畔吟 : 朝日新聞社

14）杉村廣太郎(1932)：続湖畔吟：日本評論社

15）杉村廣太郎 (1935)：続々湖畔吟：日本評論社

16) 杉村楚人冠(1938) : 新選文 : 楚人冠全集第 12 巻 : 日本評論 社, 1 - 155

17) 杉村楚人冠(1939)：とつおいり : 楚人冠全集第 16 巻 : 日本 評論社, 65 - 176

18) 杉村楚人冠(1985): 湖畔吟 : 白馬城見取圖 : 単独舎

19）杉村楚人冠邸現況平面図 : 我孫子市教育委員会提供

20) 杉村楚人冠(1937) : 白馬城 : 白馬城放語 : 楚人冠全集第 1 巻 : 日本評論社, 2 - 16

21）杉村楚人冠(1937）: 白馬城：七坪半の「別莊」：楚人冠全集 第 1 巻 : 日本評論社, 30 - 33

22）杉村廣太郎 (1932) : 続湖畔吟 : むらさきの花 : 日本評論 社, $243-245$

23）杉村家蔵 我孫子市教育委員会提供

24）杉村楚人冠(1938) : 新選文 : 黄葉 : 楚人冠全集第 12 巻 : 日 本評論社, $122-124$

25）杉村廣太郎(1935)：続々湖畔吟：あふさかさう：日本評論 社, $128-132$

26) 杉村廣太郎 (1935) : 続々湖畔吟 : 晚春の花 : 日本評論社, $57-60$

27) 杉村廣太郎(1928) : 湖畔吟 : やよひ : 朝日新聞社, $154-157$

28) 杉村楚人冠(1938) : 新選文 : 冬晴 : 楚人冠全集第 12 巻 : 日 本評論社, $63-64$

29) 杉村廣太郎(1928) : 湖畔吟 : 櫻 : 朝日新聞社, $94-97$

30) 杉村廣太郎(1932)：続湖畔吟：つばきの會 : 日本評論 社, $223-226$

31) 杉村廣太郎(1928)：湖畔口今 : 椿 : 朝日新聞社, $104-107$

32) 杉村楚人冠(1937) : 白馬城 : 庭さきの茸狩 : 楚人冠全集第 1 巻 : 日本評論社, 33

33) 杉村楚人冠(1937) : 白馬城 : 到る處の淸水 : 楚人冠全集第 1 巻 : 日本評論社, 40

34) 杉村廣太郎(1932)：続湖畔吟 : 庭樹 : 日本評論社, $66-70$

35）杉村廣太郎(1935）: 続々湖畔吟 : 作らぬ花 : 日本評論社, 88-89

36) 杉村廣太郎 (1935) : 続々湖畔吟 : 秋の明るさ : 日本評論 社, 180 - 183

37) 杉村廣太郎 (1935) : 続々湖畔吟: 落葉: 日本評論社, $313-316$ 